\title{
AMBIVALENCE AND INTERDISCIPLINARITY: The Future of Jewish Studies
}

\author{
Laura S. Levitt
}

\section{ABSTRACT}

Laura Levitt writes a response to the articles in a special issue of Shofar entitled "New Approaches to Teaching Jewish Studies." She notes that the collection of articles is presented in the spirit of collaboration and better practices. Considering the current situation in Jewish Studies as "the best and worst of times," Levitt examines the range of new and ever more sophisticated and nuanced studies of Jewish literatures, cultures, histories, ethnographies, languages, music, performance, and ritual practices against the backdrop of the precarious situation for scholars and Jewish Studies at today's universities. She speculates on how Jewish Studies might fit into a new interdisciplinary environment.

Twas the best of times, it was the worst of times, it was the age of wisdom, it was the age of foolishness, it was the epoch of belief, it was the epoch of incredulity, it was the season of Light, it was the season of Darkness, it was the spring of hope, it was the winter of despair, we had everything before us, we had nothing before us, we were all going direct to Heaven, we were all going direct the other wayin short, the period was so far like the present period, that some of its noisiest authorities insisted on its being received, for good or for evil, in the superlative degree of comparison only.

—Charles Dickens, A Tale of Two Cities

Reading about how my colleagues teach their basic courses I am humbled. In part, we do not always value the labors of teaching and yet it is in our classrooms where we are often most animated making the work we do come alive for our students. The classroom is one of the places we regularly enact what we love for a new generation. At its best, this is a daunting task. Reading these account of extraordinary teaching, creative pedagogy, and imaginative syllabi, I feel both inspired and overwhelmed. There is so much more

\section{4 | SHOFAR 32.3 (2014): 124-129}


that I could be doing and these contributions each offer advice on how I might make my own classes more compelling. But I do not want to suggest that readers need to feel defeated when reading these contributions. This collection is presented in the spirit of collaboration and better practices. We are, as Alan Levenson suggests, compelled as teachers to bring ourselves more fully into the classroom offering our students a way into the texts, the tones, the tastes, the performances that move us. We cannot simply replicate the practices of others in our own classes. These pieces suggest instead that we embrace what we love and go there. What these courses make clear is the breadth, the range of content that can and does animate Jewish pasts and Jewish presents. And together all of these efforts point towards the production of still more knowledge about Jews, Jewishness, and Judaism in Jewish Studies going forward.

In a different way, these essays and sample syllabi make vivid the challenge Judith Baskin poses at the end of her engaging essay on the state of the field of Jewish Studies and its history in North America. My remarks build on the contradictions noted by Baskin. These are the best and the worst of times for Jewish study in North America. Whether we follow Dickens or Kohelet, the doubleness that marks this historic moment in the profession is great. As Baskin argues the heady excitement of new chairs and new programs that marked the mid- to late-twentieth century has given way. With established programs and excellent graduate students, the field is, in many ways, thriving. The intellectual energy and critical engagement that marks contemporary Jewish Studies scholarship is, as these essays make clear, very much present in our classrooms but it is also necessarily apparent in a full range of scholarly venue. We see evidence of this creative productivity in conference papers and special issues of journals devoted to both emerging topics as well as efforts to revisit and reconceptualize more established genres, issues, questions, or entire subfields of Jewish Studies. This vitality is also apparent in the publication of new book series like those at Rutgers, Indiana, NYU, Stanford, Brandeis, and Wayne State Presses. The field is growing. As some of these contributions argue there are now a range of new and ever more sophisticated and nuanced studies of Jewish literatures, cultures, histories, ethnographies, languages, music, performance, and ritual practices.

And, yet, as Baskin suggests, the Humanities and Social Sciences, the fields, disciplines, and critical discourses at the heart of Jewish Studies are all in trouble. The economic downturn and the radical reduction in 


\section{6 | LAURA S. LEVITT}

public funding for higher education to support students at all institutions and most especially the funding of public institutions as such all portend fewer tenure-track or even full time jobs in our various fields of inquiry. The future is not quite so bright and may be much worse. In Jewish Studies the kinds of private donor and foundation funding that once created and sustained the growth of Jewish Studies programs across North America, perhaps again for better and for worse are dwindling. ${ }^{1}$ As Baskin suggests, even in many colleges and universities with endowed chairs and centers, the original gifts are no longer enough to sustain those very programs. As we are doing some of our very best thinking and teaching and writing and research, the painful truth is that the places that sustain us, the colleges and universities that employ us as scholars and teachers, are becoming more precarious. Even the best of our graduate students are not finding gainful employment. There are fewer jobs and the demands on faculty in those positions are greater. We are all being asked to do more with less. And most of us are expendable. For those already on the periphery, the itinerant workers, the adjunct and non-tenure track faculty in our various fields, there is already no job security. The future is precarious. We have already lost many promising and talented scholars and teachers to other professions. And these losses will continue to grow as young and talented graduate students continue to find it difficult to procure full-time work. These are, indeed, the best and the worst of times.

As celebratory as this collection is I so appreciate the fact that Judith Baskin frames these efforts with her sober assessment. That said, what is the possibility that out of this initial effort to explore best practices that the kind of visionary teaching seminar that Lefkovitz, Shneer, and Tenenbaum envision might come to fruition? And how might we imagine its outcomes? And here I purposely deploy the language of our neoliberal moment, the language of "outcomes," because here too I see a double message. In the current moment, the moves to interdisciplinary approaches to teaching and scholarship are neither singular nor uniform. On the one hand, I believe that a summer institute that might build on the kinds of questions Lefkovitz, Shneer, and Tenenbaum pose might just equip some of our best and brightest graduate students and early career scholars for a future where the Humanities and Social Sciences are no longer bound by departments and specific disciplinary units.

This is already becoming the case at a place like Arizona State University where the university has combined for example, History, Philosophy 
and Religious Studies in something it calls "the School of Historical, Philosophical, and Religious Studies." In this kind of new environment interdisciplinary work helps consolidate teaching, and perhaps research, across the Humanities with less differentiation based on specific disciplinary fields. In these settings our graduate students and early-career scholars may find themselves teaching increasingly synthetic courses in the Humanities or the Social Sciences. Their role in these programs will be to more fully integrate Jews, Jewishness, and Judaism into those broader curricular discourses and practices. Here "thinking with Jews" may be especially productive. This, is at least the hope of many of us as we look towards the future.

On the other hand, in a place like Temple University where I teach, the recent implementation of "Responsibility Based Budgeting" or "Revenue- Based Budgeting" (RCM) offers a different scenario. ${ }^{3}$ At Temple at the present moment, the various colleges and schools housed within the university are now in competition with each other for limited bodies and resources. And so the Jewish Studies faculty who teach courses for us on film and arts education in the schools of music and art and dance or our colleges in the school of education are increasingly unable to cross-list their courses in our program. Because our colleges are now competing against each other, we are less able to work in interdisciplinary ways. This too is a part of the future before us. In this mode interdisciplinary courses may become that much more difficult to nurture. Here market values are challenging cooperation and collaboration.

In the late 1990s in the heady days of the "feminization of Jewish Studies"4 a project I was very much a part of, I published with Miriam Peskowitz not only a special issue of Shofar devoted to engendering new Jewish Knowledge, but the collection, Judaism Since Gender. ${ }^{5}$ And it is not surprising that some of the people central to those discussions about gender continue to lead the way in reimagining the field. Judaism Since Gender opens with a sustained forum built around an essay on teaching precisely the introductory course. In that case it was Duke University's "Introduction to Jewish Religious History." In her essay, "Engendering Jewish Religious History,” Miriam Peskowitz de- and reconstructs that basic course to ask questions about how not only to bring Jewish women into the discussion but how to think more critically about the constructed nature of the categories of gender as we knew them at that time. I still teach this essay and many of the diverse response that constitute the first section of our book in my graduate foundations course on Judaism. Together those essays continue to offer a 


\section{8 | LAURA S. LEVITT}

glimpse of the state of the field in relation to questions of gender. In a different way, the contributions to this special issue tell us something about the state of Jewish Studies more broadly construed now. In the present moment there is much more attention to gender and sexuality in a range of manifestations, and there are other considerations. There is so much more racial, ethnic, linguistic, and cultural diversity as we consider the histories of the Jews across the globe. And even in these times, ${ }^{7}$ we find new knowledge, new teaching, and ongoing critical engagement. All of this is to be celebrated and perhaps all the more so given the constraints that mark the underside of this not so heady present moment.

\section{NOTES}

1. See most recently Aaron Hughes' essay in the Chronicle of Higher Education, "Jewish Studies is Too Jewish," http:// chronicle.com/article/Jewish-Studies-Is-TooJewish/145395 / and Zachary Braiterman's earlier pointed and compelling account of the politics of these interventions, "Conservative Money in Jewish Studies: Investigating the Tikvah Fund," http://zeek.forward.com/articles/117374/. I also need to note that as the director of Temple University's Jewish Studies program I was personally responsible for securing ten years of funding from the Posen Foundation to create and sustain a certificate program in Secular Jewish Studies. This funding was vital to Temple's program. It was a critical intervention of funds in a small and precarious program. This funding helped pave the way for many other things including bringing the Philadelphia Jewish Archives to Temple and the revitalization and building of the Feinstein Center for American Jewish History at Temple, a center now thriving under the leadership of Lila Corwin Berman, the Murray Freidman Chair of American Jewish History.

2. Although there are still individual undergraduate majors and minors in these separate fields, their administration is combined. At Arizona State this combined school/department also seems to include Jewish Studies. The School of Historical, Philosophical and Religious Studies is located within the College of Arts and Sciences.

3. For more on this budgeting model see Temple University's official answers to frequently asked questions at http:/ / www.temple.edu/cfo/decentralized-budgeting/documents/FAQ_001.pdf or for a different take from faculty from across the university, see the following forum in the Temple University Faculty Herald, http:// www.temple.edu/herald/43_2/ResponsibilityCenteredBudgeting.htm

4. See Hillel Halkin, "Feminizing Jewish Studies, "Commentary Magazine, 105.2( February, 1998), 39-45 and Scott Heller, "The New Jewish Studies: Defying Tradition and Easy Categorization," The Chronicle of Higher Education, January 29,, 1999.

5. See Laura Levitt and Miriam Peskowitz, guest co-editors, "Engendering Jewish Knowledges," Shofar: An Interdisciplinary Journal For Jewish Studies 14.1 (Fall,

\section{SHOFAR 32.4}




\section{AMBIVALENCE \& INTERDISCIPLINARITY: THE FUTURE OF JEWISH STUDIES | 129}

1995) and Miriam Peskowitz and Laura Levitt eds., Judaism Since Gender, New York: Routledge, 1997. I also want to acknowledge Judith Baskin's important contribution to these efforts and call attention to the ground-breaking work that Baskin did as editor of Jewish Women in Historical Perspective Detroit: Wayne State Press, 1999. I also want to note the significant work that both Judith Baskin and Shelley Tenenbaum did in helping create the field of Jewish women's studies more generally as leaders of the AJS women's caucus and as editors of various works that established Jewish women's studies. In 1994 Baskin and Tenenbaum collected and published one of the very first compendium of syllabi, Judith Baskin, and Shelly Tenenbaum, eds., Gender and Jewish Studies: A Curriculum Guide New York: Biblio Press, 1994. I was honored to have been invited by Tenenbaum and Baskin to contribute to that early collection. In addition to this work with Lynn Davidman, in 1996 Shelley Tenenbaum edited, Feminist Perspectives on Jewish Studies published by Yale University Press. This book asked how Jewish women's studies was transforming the various subfields of our discipline, religious studies, history, literature, anthropology and sociology, and even film studies. I remind readers of the abiding commitments of these two important contributors to this special issue. I believe these commitments speak to their ongoing engagement and leadership roles in the production of all kinds of new knowledge in the field of Jewish Studies.

6. Miriam Peskowitz, "Engendering Jewish Religious History," in part one, "Knowledges," Judaism Since Gender, 17-39. This essay is followed by 18 short pieces by a range of scholars responding to this essay with reflections on how they each work to produce new knowledge about Jews, Judaism and Jewishness, 40-146.

7. Some of these efforts can be seen in various strong journals in the field, the AJS Review, Jewish Social Studies, but also in the powerful innovations of AJS Perspectives that has offered, over the past few years, issues devoted to a range of fascinating topics as well as new development in the field. Recent issues have addressed some of the following topics: Museums, Marriage, Iranian, and Iraqi Jewish communities, a Muslim Issue, a religion and a secular issues, as well as an issue devoted to the Apocalypse. These back issues are now available online at http:// www.ajsnet.org/perspectives.htm. 